\title{
Binding of galectin-1 to breast cancer cells MCF7 induces apoptosis and inhibition of proliferation in vitro in a 2D- and 3D- cell culture model
}

Pamina Geiger ${ }^{1}$, Barbara Mayer ${ }^{2}$, Irmi Wiest $^{1}$, Sandra Schulze ${ }^{1}$, Udo Jeschke ${ }^{1 *}$ (i) and Tobias Weissenbacher ${ }^{1}$

\begin{abstract}
Background: Galectin-1 (gal-1) belongs to the family of $\beta$-galactoside-binding proteins which primarily recognizes the Galß1-4GIcNAc sequences of oligosaccharides associated with several cell surface glycoconjugates. The lectin recognizes correspondent glycoepitopes on human breast cancer cells. Galectin-1 is expressed both in normal and malignant tissues. Lymphatic organs naturally possessing high rates of apoptotic cells, express high levels of Galectin-1. Furthermore galectin-1 can initiate T cell apoptosis. Binding of galectin-1 to trophoblast tumor cells presenting the oncofetal Thomsen-Friedenreich (TF) carbohydrate antigen inhibits tumor cell proliferation. In this study we examined the impact galectin-1 has in vitro on cell proliferation, apoptotic potential and metabolic activity of MCF-7 and T-47D breast cancer cells in dependence to their expression of the Thomsen-Friedenreich (TF) tumor antigen.
\end{abstract}

Methods: For proliferation and apoptosis assays cells were grown in presence of 10, 30 and $60 \mu \mathrm{g} \mathrm{gal-1/ml} \mathrm{medium.}$ Cell proliferation was determined by a BrdU uptake ELISA.

Detection of apoptotic cells was done by M30 cyto death staining, in situ nick translation and by a nucleosome ELISA method. Furthermore we studied the impact galectin-1 has on the metabolic activity of MCF-7 and T-47D cells in a homotypic three-dimensional spheroid cell culture model mimicking a micro tumour environment.

Results: Gal-1 inhibited proliferation of MCF-7 cells (strong expression of the TF epitope) but did not significantly change proliferation of T-47D cells (weak expression of the TF epitope). The incubation of MCF-7 cells with gal-1 raised number of apoptotic cells significantly. Treating the spheroids with $30 \mu \mathrm{g} / \mathrm{ml}$ galectin-1 in addition to standard chemotherapeutic regimes (FEC, TAC) resulted in further suppression of the metabolic activity in MCF-7 cells whereas T-47D cells were not affected.

Conclusions: Our results demonstrate that galectin-1 can inhibit proliferation und metabolic cell activity and induce apoptosis in breast tumor cell lines with high expression levels of the Thomsen-Friedenreich (TF) antigen in monolayer and spheroid cell culture models.

Keywords: Galectin 1, Thomsen-Friedenreich, MCF7, Spheroid, Proliferation, Apoptosis

\footnotetext{
* Correspondence: udo.jeschke@med.uni-muenchen.de

${ }^{1}$ Department of Obstetrics and Gynecology, LMU Munich-Innenstadt,

Maistrasse 11, 80337 München, Germany

Full list of author information is available at the end of the article
} 


\section{Background}

Galectins belong to the family of lectins and are defined by specifically binding $\beta$-galactosides and by a conserved sequence motif of amino acids in the carbohydrate recognition domain (CRD). The first family member to be described, Galectin-1 (gal-1), is a homodimeric protein with a single carbohydrate recognition domain of 134 amino acids [1]. It has been identified to be expressed in lymphoid organs such as the thymus and lymph nodes, in activated macrophages and T cells. Furthermore its expression is balancing immune tolerance [2]. LacNAc is the basic ligand recognized by gal-1, but it also shows increased avidity to multiple Galß1-4GlcNAc sequences presented on branched $\mathrm{N}$-linked or on repeating LacNAc-residues on $\mathrm{N}$ - and O-linked glycans. Having a single CRD, gal-1 associates non-covalently under physiological conditions to form a homodimer and such becomes functionally bivalent. The bivalent nature entails glycan-mediated cross-linking of cell surface receptors believed to be essential in inducing signaling events [3, 4]. Extracellularly, by binding its glycan ligands, gal-1, exerts various biological effects in different tissues and on cells, including cell adhesion $[5,6]$, metastasis [7], cell growth regulation [8, 9], immunosuppression [10] and apoptosis [3].

Treatment of breast cancer tumor cells with galectin-1 leads to reduced cell binding to laminin and plasma or placental fibronectin [11]. Increased binding potential for galectin-1 in breast cancer cells seems to correlate with a positive lymph node status and with tumor size and stage, whereas the presence of galectin-1 was identified as a factor that correlates with a lack of metastatic lesions in lymph nodes. These results indicate quantitative cell-type-dependent requirements of galectin ligand presentation during the metastatic cascade [11].

Gal-1 expression is also found in the placenta. The placenta plays a key role in balancing local immuntolerance which is essential for the mother to accept the embryo during pregnancy. This complex process of tolerance allowing the foetal survival is controlled at the embryo-maternal interface by factors deriving as well from decidualized endometrium as from the trophoblast itself. Trophoblasts display various strategies to evade the destructive attack of the maternal immune response including expression of non-classical MHC class I antigens and of complement regulatory proteins $[12,13]$. Chorioncarcinoma cell lines were evaluated as an experimental model of trophoblastderived immunoregulation [14]. We found a strong expression of the Thomsen-Friedenreich (TF) tumour antigen in the choriocarcinoma cell line BeWo $[15,16]$.

The TF antigen (galactose- $\beta 1-3 \mathrm{~N}$-acetylgalactosamine; Gal $\beta 1-3 G a l N A c \alpha 1)$ is a tumor-associated disaccharide which is occluded by covering structures and inaccessible to the immune system on the cell surface in most healthy tissues. It is however exposed and immunoreactive on most human carcinomas and T-cell lymphomas [17]. Galectin-1 binding to BeWo trophoblast tumor cells presenting the TF antigen inhibits tumor cell proliferation [16]. Large amounts of TF tumor antigen have as well been detected on the outer surface membranes of human breast carcinomas $[17,18]$.

The TF antigen and galectins have also already been implicated in tumour cell adhesion and tissue invasion. Gal-1 and gal-3 appear to participate both in the homotypic aggregation of human breast carcinoma cells MDA-MB-435 and their adhesion to the endothelium. This adhesion seemed to be mediated involving TF antigen, as it could be inhibited by a TF-antigen specific peptide [19].

In a former study we showed that gal-1 shows apoptotic potential in the human breast cancer line MCF-7 in combination with additional stress stimuli like hyperthermia or the removal of $\mathrm{CO}_{2}$ and FCS for $20 \mathrm{~h}$ [20].

In this article we describe that the binding of gal- 1 on human breast cancer cells can induce inhibition of proliferation and apoptosis in dependence of their expression of the TF antigen.

When examining basic biological tumor cell functions in vitro, conventional monolayer cultures can only act as a very limited cancer model when it comes to sustaining the characteristics of the original tumor in vitro. Three dimensional spheroid cultures of cancer cells may reflect properties of tumors better than those traditional monolayer cultures, since they come closer to the in vivo situation regarding cell differentiation, proliferation, and cell environment, i.e., cell-cell contacts and different growth areas [21-23]. In this article we also describe that in a homotypic spheroid model as well binding of gal-1 on human breast cancer cells can reduce metabolic cell activity in dependence of their expression of the TF antigen.

\section{Methods}

Breast cancer cell lines and galectin-1 treatment

For this study we used MCF-7 and T-47D human breast cancer cell lines obtained from ATCC. Cells were grown in DMEM (Biochrom, Germany) supplemented with $10 \% \mathrm{v} / \mathrm{v}$ foetal calf serum (PAA, Germany) and $2 \mathrm{mM}$ L-glutamin (Sigma-Aldrich, Munich, Germany), without antibiotics and antimycotics. For proliferation assays and apoptosis assays cells were grown in the presence of 10, 30 and $60 \mu \mathrm{g}$ galectin-1 (Sigma-Aldrich) per ml serum + 10 \% FCS for $48 \mathrm{~h}$. Untreated cells were used as controls.

\section{Immunocytochemistry}

Each cell line was investigated for TF antigen expression by immunocytochemistry. Cells were grown on threewell multitest slides (Roth, Karlsruhe, Germany) to subconfluency, then dried, wrapped and stored at $-80{ }^{\circ} \mathrm{C}$. 
After thawing, cells were briefly fixed with formalin (Merck, Darmstadt, Germany; 5 \% in PBS (Biochrom), $5 \mathrm{~min}$ ). The primary anti-TF antibody (Table 1) was diluted to $2 \mu \mathrm{g} / \mathrm{ml}$ with PBS and incubated with the slides overnight at $4{ }^{\circ} \mathrm{C}$. After washing this was followed by incubation with the biotinylated secondary antibody from the Vectastain ${ }^{\circ}$ Elite ABC Mouse IgG Kit (Vector Laboratories, Peterborough, UK) diluted 1:200 for 30 min. Furthermore we used the Vectastain ${ }^{\bullet}$ Elite ABC Kit for visualization according to the instructions of the manufacturer. The slides were finally embedded in mounting buffer and examined with a Zeiss (Jena, Germany) Axiophot photomicroscope. Images were aquired with a digital camera system (Axiocam, Zeiss).

\section{BrdU cell proliferation assay}

Cell proliferation was analyzed with a 5-bromo-2'-deoxyuridine (BrdU) labelling and detection kit (Roche Diagnostics GmbH, Mannheim, Germany) according to the manufacturer's instructions. In 96-well tissue culture plates, cells $\left(1 \times 10^{5}\right.$ in $0.1 \mathrm{ml}$ cell culture medium) were grown for $72 \mathrm{~h}$ in the absence (controls) and presence of 10, 30 and $60 \mu \mathrm{g} / \mathrm{ml}$ gal-1. For labelling cells were incubated with BrdU for $3 \mathrm{~h}$, then fixed and subsequently BrdU incorporation into the cellular DNA was measured by an ELISA technique. Cellular proliferation is expressed as percentage compared to the control. At least 8 replicates were performed with each cell line.

\section{M30 cytoDEATH apoptosis assay}

Caspase activity is one of the earliest apoptosis markers. The M30 cytodeath assay detects caspase-cleaved Cytokeratin 18 in epithelial cells. Culture slides with MCF-7 cells grown in the presence of galectin-1 as described were treated according to the manufactures protocol (Alexis Biochemicals). Slides were washed in PBS and then fixed in ice-cold pure methanol at $-20{ }^{\circ} \mathrm{C}$ for $30 \mathrm{~min}$. After being washed twice with PBS they were incubated with M30 CytoDEATH Fluorescein antibody (Table 1) for $30 \mathrm{~min}$ at $15-25^{\circ} \mathrm{C}$ and then washed again twice before immunocytochemical evaluation. 10 replicates were performed.

\section{In situ nick-translation (ISNT) apoptosis assay}

The in situ nick-translation technique (ISNT) was used to staining DNA fragmentation and apoptotic bodies on cell culture slides [20]. Slides were incubated with proteinase K (20 $\mu \mathrm{g} / \mathrm{ml}$, Qiagen, Germany) for $15 \mathrm{~min}$ at room

Table 1 Antibodies used for the study

\begin{tabular}{lllll}
\hline Antigen & Antibody & Isotype & Concentration/Dilution & Source \\
\hline TF & NM-TF1 & Mouse lgM & $2 \mu \mathrm{g} / \mathrm{ml}$ & Glycotope \\
M30 & ALX-804-590-T200 & Mouse lgG & $1: 15$ & Alexis \\
\hline
\end{tabular}

temperature. After rinsing with distilled water the endogenous peroxidase was quenched with $0.3 \%$ hydrogen peroxide for $10 \mathrm{~min}$. Being rinsed once more, the slideswere then equilibrated in nick buffer (Tris, $\mathrm{MgCl}_{2}, \mathrm{~B}_{\text {-Mercaptoetha- }}$ nol, $20 \mathrm{mg} / \mathrm{ml}$ BSA, distilled water) at room temperature for $10 \mathrm{~min}$. By incubating the slides with dNTPs and biotinylated 7-dATP (Gibco, USA) diluted in nick buffer for 65 min at $37^{\circ} \mathrm{C}$, the in situ nick-translation was performed. Terminating buffer $(0.3 \mathrm{~mol} / \mathrm{L}$ sodium chloride and $0.03 \mathrm{~mol} / \mathrm{L}$ sodium citrate) was used to rinse the chamber slides at room temperature for $15 \mathrm{~min}$. After having washed the slides in PBS, they were incubated with extravidin-peroxidase (Sigma, Germany) at room temperature for $30 \mathrm{~min}$. AEC-substrate (Dako, Denmark) was used for colour development. Afterwards the slides were counterstained with haemalaun, then washed and mounted. The specificity of ISNT reactivity was confirmed by human epidermis and lymph node sections. 10 replicates were performed. Negative controls were performed by incubation in nick buffer without dNTPs and biotinylated 7-dATP.

\section{Immunocytochemical evaluation of apoptosis assays}

For the evaluation of early apoptosis by M30 cytoDEATH staining and late apoptosis (in situ nick-translation) the intensity and distribution of the immunocytochemical staining reaction was evaluated using a semi-quantitative method (IRS-score) as previously described [24]. The rate of apoptosis for M30 cytoDEATH and in situ nick translation was determined by counting 1500 cells per chamberslide.

\section{Cell death detection ELISA}

Apoptosis was also detected using a quantitative threestep photometric enzyme immunoassay. The Cell Death Detection ELISA ${ }^{\text {plus }}$ kit (Roche Diagnostics GmbH, Mannheim, Germany) detects cytoplasmic histoneassociated DNA fragments (mono- and oligonucleosomes) in vitro after induced cell death. This assay uses monoclonal mouse antibodies directed against histones and DNA in a quantitative sandwich enzyme immunoassay. Specific mono- and oligonucleosomes in the cytoplasmic fraction of cell lysates can thus be detected. At first the anti-histone antibody was fixed adsorptively on the wall of the microplate where non-specific binding sites were saturated and hence blocked. Second the nucleosomes in the sample were bound to the immobilized anti-histone antibody via their histone component. Third, the DNA part of the nucleosome reacted with the anti-DNA-peroxidase. After washing unbound samples and reagents, the amount of peroxidase ligated in the immunocomplex was determined colorimetrically using ABTS as substrate. Results are presented in Units; Unit Conversion: $1 \mathrm{mU}=1 \times 10-3$ OD $(1 \mathrm{mU}=0.001 \mathrm{OD})$. A total of 8 replicates were performed. 


\section{Spheroid culture}

3D cell culture was performed using a modified liquid overlay technique as described previously [25]. Briefly, monolayer cultures of the breast cancer cell lines MCF-7 and T-47D were allowed to reach a minimal confluency of $90 \%$ for spheroid culture. The viability and the cell number of the cell suspensions used for spheroid culture were assessed. Only cell suspensions with a viability of at least $90 \%$ were used for spheroid culture. For spheroid formation $5 \times 10^{4}$ vital cells were seeded in $50 \mu$ cell culture medium per 96-well and cultured for $48 \mathrm{~h}$ at $37{ }^{\circ} \mathrm{C}$ in a humidified atmosphere containing $5 \% \mathrm{CO} 2$. Using this approach, a single homotypic spheroid was obtained in each well.

\section{Cancer therapy and cell viability ATP-assay}

After $48 \mathrm{~h}$ of spheroid formation, chemotherapeutic agents, namely fluorouracil combined with epirubicin and cyclophosphamide (FEC) and docetaxel combined with doxorubicin and cyclophosphamide (TAC) were administered to the spheroids in clinically relevant combinations at the peak plasma concentrations as described previously [26]. Galectin-1 was applied in a concentration of $30 \mu \mathrm{g} / \mathrm{ml}$. Medium (untreated) and solvent controls were included in each experiment. Solvents used to control the effect of the drugs were $0.2 \% \mathrm{H} 2 \mathrm{O}$ plus $0.26 \% \mathrm{NaCl}$ for FEC therapy, $0.01 \% \mathrm{H} 2 \mathrm{O}$ plus $0.21 \%$ $\mathrm{NaCl}$ for TAC treatment and $0.15 \%$ phosphate buffered saline (PBS) for galectin-1. Each treatment and control was performed in six replicates. The drugs were allowed to take effect for a total of $48 \mathrm{~h}$. Chemotherapeutics were obtained from the pharmacy of the University Hospital LMU (Munich, Germany). Treatment efficacy was assessed using an ATP assay (CellTiter-Glo ${ }^{\circ}$ Luminescence Cell Viability Assay, G8461, Promega, Germany) to quantify cell survival in vitro. Mean cell survival was expressed as percent of residual metabolic activity relative to the solvent controls.

\section{Statistical analysis}

IBM SPSS Statistics for Windows, Version 22.0. ((IBM, Ehningen,Germany) was used for collection, processing, and statistical data analysis. The non-parametrical Wilcoxon test for comparison of the means was used for statistical analysis. P-values $<0.05$ were considered statistically significant. For statistical analysis of the results obtained in the spheroid model, the student's $t$-test was performed for comparison of two samples. For comparisons of more than two samples, analysis of variance (ANOVA) with post-hoc Sidak correction was done.

\section{Results}

Expression of TF antigen in breast cancer cell lines

Expression of the Thomsen-Friedenreich (TF) antigen as a target for gal-1 binding was investigated in human breast cancer cells of the cell lines MCF-7 and T-47D by immunocytochemistry. Staining results are presented in Fig. 1. MCF-7 cells showed strong expression (Fig. 1a) whereas T-47D showed only weak expression of the TF epitope (Fig. 1b). All magnification 10x lens.

\section{Cell proliferation assay}

As demonstrated in Fig. 2a, gal-1 inhibits proliferation of MCF-7 cells in a concentration-dependent manner. The addition of gal- 1 at $10 \mu \mathrm{g} / \mathrm{ml}, 30 \mu \mathrm{g} / \mathrm{ml}$, and $60 \mu \mathrm{g} / \mathrm{ml} \mathrm{re-}$ duced cellular 5-bromo-2'-deoxy-uridine (BrdU)-uptake significantly to $83.8 \%(p=0.008), 67.4 \%(p=0.013)$, and to $76.2 \%(p=0.006)$ respectively, compared to non-treated control cultures (100\%). Gal-1 did not significantly stimulate proliferation of T-47D cells at concentrations of $10 \mu \mathrm{g} / \mathrm{ml}, 30 \mu \mathrm{g} / \mathrm{ml}$, and $60 \mu \mathrm{g} / \mathrm{ml}$ ( $p=0.109$ ) (Fig. 2b).

\section{Evaluation of apoptosis by M30 cytoDEATH}

The rate of very early apoptosis detected by M30 staining in untreated for MCF-7 cells had a mean of $1.7 \%$ (Fig. 3a, e) evaluated by a semi-quantitative method. In cells treated with $60 \mu \mathrm{g} / \mathrm{ml}$ gal- 1 for $48 \mathrm{~h}$ the rate of very early apoptosis is elevated to up to $6.7 \%$ for MCF-7 cells $(p=0.005$, Fig. 3b, e).

\section{Evaluation of apoptosis by in situ nick-translation (ISNT)}

The normal rate of apoptosis in MCF-7 breast cancer cells had a mean of $1.4 \%$ detected by ISTN (Fig. 3c, e). The viability of the cells manifested itself in a regular growth and a good range of mitosis. The exposure with $60 \mu \mathrm{g} / \mathrm{ml}$ gal-1 for $48 \mathrm{~h}$ significantly increased apoptosis in MCF7-cells up to $3.6 \%(p=0.01$, Fig. $3 d$, e).

\section{Evaluation of apoptosis by cell death detection ELISA}

DNA fragmentation was quantified by examining the cytoplasmic histone-associated DNA fragments (mononucleosomes and oligonucleosomes). The incubation of MCF-7 cells with 10, 30 and $60 \mu \mathrm{g} / \mathrm{ml}$ gal-1 enhancing apoptosis to a maximum of 2.1, 2.7 and $3.2 \mathrm{U}$, respectively (Fig. 4), reaching statistically significance for $10 \mu \mathrm{g} / \mathrm{ml}(p=0.018)$, $30 \mu \mathrm{g} / \mathrm{ml} \quad(p=0.018)$ and $60 \mu \mathrm{g} / \mathrm{ml} \quad(p=0.028)$ gal-1 incubation.

\section{Evaluation of metabolic activity in the spheroid model}

Homotypic spheroids were prepared from human breast cancer cells lines and treated with various agents. Metabolic activity after treatment was measured using the ATP assay (Fig. 5). Treatment of MCF-7 cells with $30 \mu \mathrm{g} / \mathrm{ml}$ gal-1 decreased the metabolic activity to $79.16 \%$ of solvent control compared to untreated cells $(93.5 \%)(p=0.027)$. In combination with $1 x P P C$ FEC $30 \mu \mathrm{g} / \mathrm{ml}$ gal-1 further reduced the metabolic activity to $21.9 \%$ of solvent control compared to only $38.4 \%$ FEC alone $(p=0.016)$. The same could be shown for 


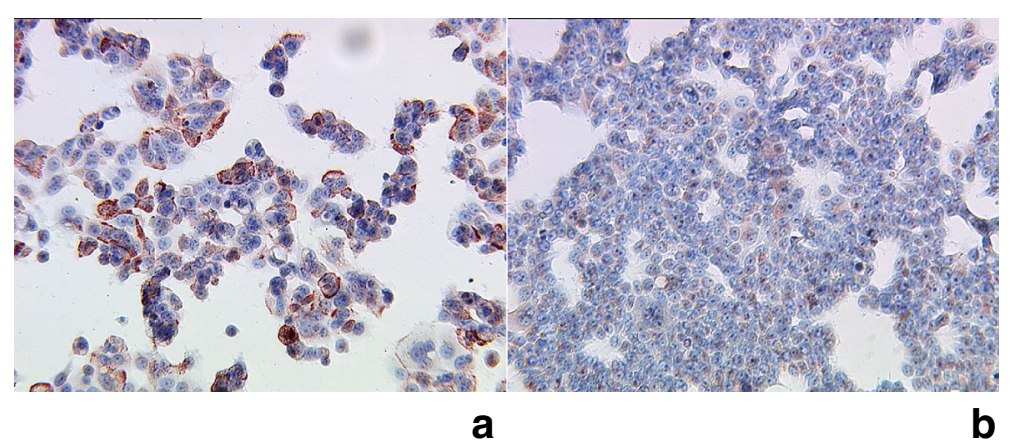

Fig. 1 Strong expression of TF in MCF-7 cells (a). T47-D cells (b) showed only weak expression of TF. All magnification 10x lens

combination of $30 \mu \mathrm{g} / \mathrm{ml}$ gal-1 with 1 xPPC TAC which led to a reduction to $46.3 \%$ of solvent control compared to $56.9 \%$ TAC alone $(p=0.031)$ (Fig. $5 \mathrm{a})$.

In T-47D cells the treatment of homotypic spheroids with $30 \mu \mathrm{g} / \mathrm{ml}$ gal-1 could not significantly reduce the metabolic activity to $92.3 \%$ of solvent control compared to untreated cells (97.2\%). Also the addition of $30 \mu \mathrm{g} /$ $\mathrm{ml}$ gal-1 to $1 \times$ PPC FEC did not significantly alter the rate of metabolic activity (65.2\% of solvent control compared to $63.4 \%$ for FEC alone). Neither could the addition of $30 \mu \mathrm{g} / \mathrm{ml}$ gal-1 to $1 \mathrm{xPPC}$ TAC induce a significant effect (71.9\% of solvent control compared to $74.8 \%$ for TAC alone) (Fig. 5b).

\section{Discussion}

Within this study we could show that MCF-7 breast cancer cells show a strong expression of the TF antigen or epitope. Ligation of galectin-1 induced inhibition of proliferation as well as metabolic cell activity and onset of apoptosis.

The Thomsen-Friedenreich (TF) antigen [27] has been known as a tumour-associated antigen for a long time
[28]. Masked and covered for example by covalently linked carbohydrates or physically seperated from the immune system, TF tumor antigen is present in most tissues on the surfaces of healthy cells. In its unsubstituted immunoreactive form it can frequently be found in cancer and precancerous conditions and in many of these cases, the increased TF occurrence correlates with the formation of metastasis and cancer progression [29]. The immunoreactive TF antigen also is expressed by fetal epithelia [30], can be found on transferrin isolated from human amniotic fluid [31] and is expressed by the syncytiotrophoblast and extravillous trophoblast [15]. The absence of TF in an immunoreactive form in non-carcinomatous postfetal tissues, its presence during an early fetal phase and its frequent occurance in carcinomas suggest that TF is a stage-specific oncofetal carbohydrate antigen.

In epithelial cells, it is mainly associated with mucin-1 (MUC1), a protein belonging to a family of highly glycosylated proteins lining the apical surface of many glandular epithelial cells. On tumour cells MUC1 is posttranslational modified leading to an exposure of the

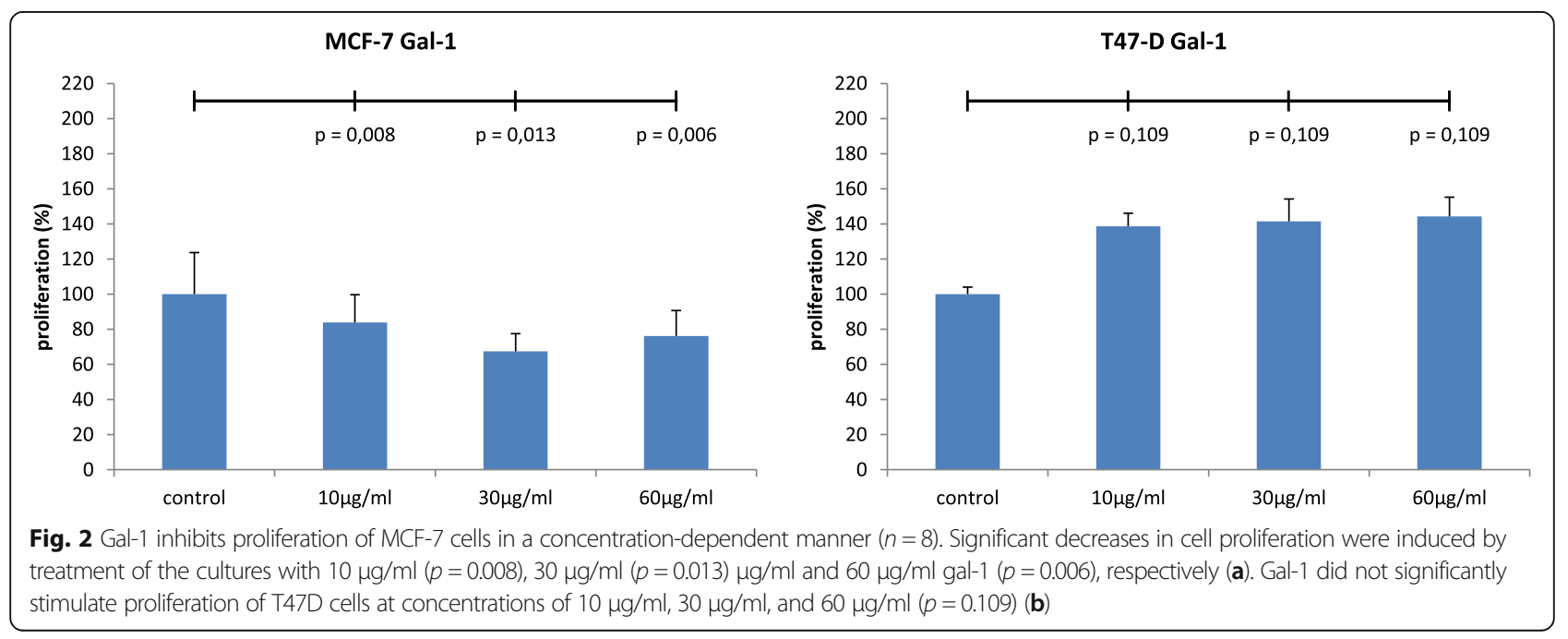



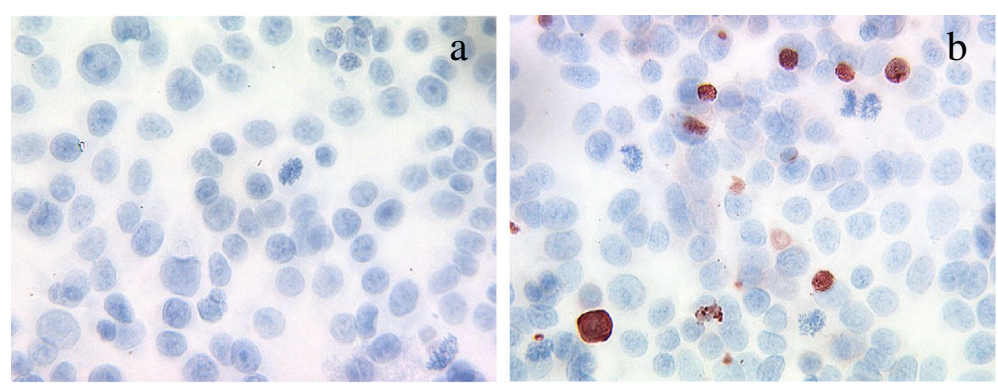

M30 MCF-7

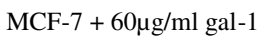

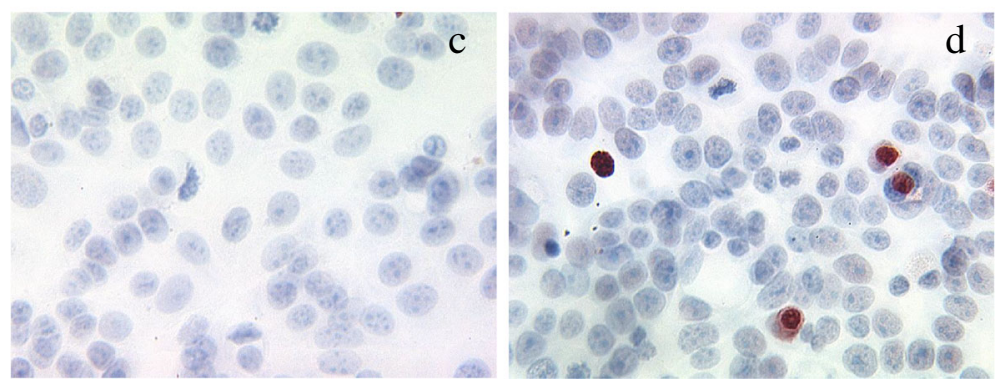

ISNT MCF-7

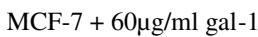

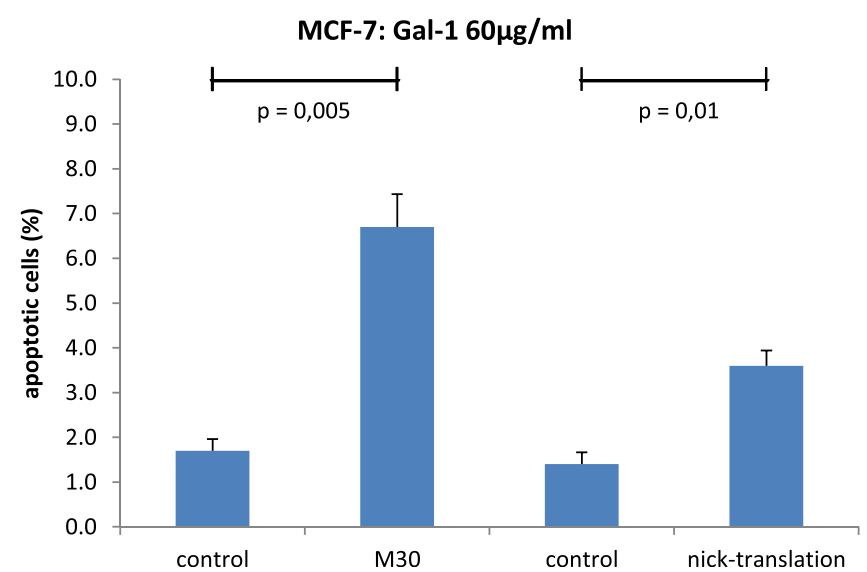

Fig. $3 \mathrm{M} 30$ staining in untreated for MCF-7 cells had a mean of $1.7 \%$ (a). In cells treated with $60 \mu \mathrm{g} / \mathrm{ml}$ gal-1 for $48 \mathrm{~h}$ the rate of very early apoptosis is elevated to up to $6.7 \%(p=0.005, \mathbf{b})$. The normal rate of apoptosis in MCF-7 breast cancer cells had a mean of $1.4 \%$ detected by in situ nick translation (ISNT, c). The incubation with $60 \mu \mathrm{g} / \mathrm{ml}$ gal-1 for $48 \mathrm{~h}$ significantly enhanced apoptosis in MCF7-cells to a maximum of $3.6 \%$ ( $p=0.01$, d). Results of M30 and ISNT staining are summarized (e) $(n=10)$

TF epitope by incomplete $O$-glycosylation. In several tumour entities, like colon [32], lung [33] or gastric cancer [34], or in cancer of the cervix uteri [35, 36], a correlation between TF expression and negative prognosis could be identified. Yet, in other tumour locations, like in breast cancer, its prognostic impact is indeterminate. On the one hand high TF expression predicted improved survival [37], then again another study identified a correlation between high tumour stage and TF expression [38].

In a former study we could demonstrate that in breast cancer patients TF is expressed on disseminated tumor cells in bone marrow (DTC-BM) as well [39]. As there is little knowledge which of the primary tumours' factors correlates with haematogenous dissemination, we have also investigated the expression of TF antigen of breast cancer tissues from patients with known BM status at the time of first diagnosis. Patients with TF-positive tumours had a favourable prognosis [40]. This contrasts to studies on gastrointestinal tumours [41]. We hypothesised that at least three factors, dissemination routes, TF-mediated metastasis formation and the immunogenicity of TF, together determine the different prognostic impact of TF expression in different tumour locations [40].

Results obtained within this study demonstrate that gal-1 only shows apoptotic potential in TF-expressing 


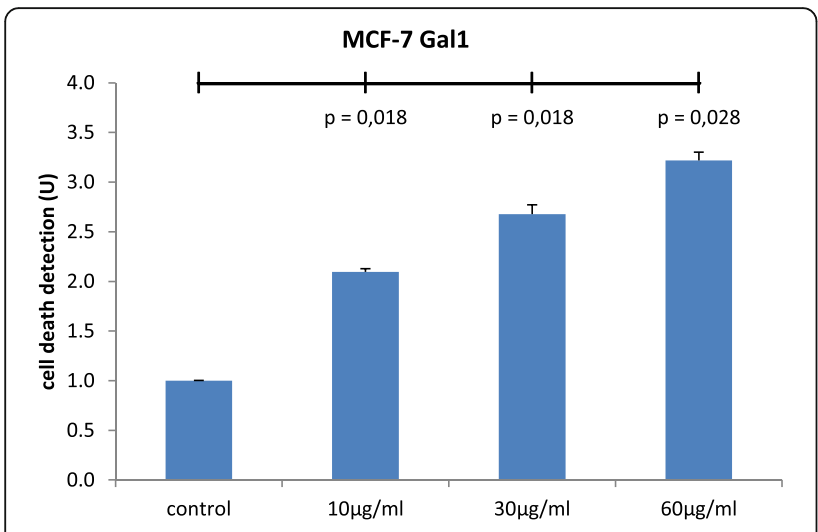

Fig. 4 The incubation of MCF-7 cells with 10, 30 and $60 \mu \mathrm{g} / \mathrm{ml} \mathrm{gal}-1$ enhanced DNA fragmentation and nucleosoma formation, reaching statistically significance for 10,30 and $60 \mu \mathrm{g} / \mathrm{ml}$ gal-1 incubation $(p=0,018 ; p=0,018 ; p=0.028)(n=8)$

breast tumor cell lines together with inhibition of proliferation. Breast cancer cells which expressed lower levels of TF showed no onset of apoptosis upon incubation with gal-1. In a preliminary study of our group apoptosis could be induced by gal-1 and additional stimuli like hyperthermia or long term removal of $\mathrm{CO}_{2}$ and FCS [20]. At a concentration of $60 \mu \mathrm{g} / \mathrm{ml}$ incubation of the cells with gal-1 for $48 \mathrm{~h}$, as done in the present study, no further stimulus was needed to significantly increase apoptosis in the 2-D model.

Apart from studying the tumor biological effects gal-1 induces in a traditional monolayer culture model, we also tested them in a homotypic spheroid model. This model can come closer to mimicking the assembly of a tumor since spheroids consist of proliferating and viable but post-mitotic cell populations as well as cells and compact structures, often in the spheroid core, which may contain necrotic or apoptotic cells [23].
In the homotypic spheroid cell culture model incubation of MCF-7 cells with $30 \mu \mathrm{g} / \mathrm{ml}$ gal- 1 for $48 \mathrm{~h}$ led to an significantly decreased level of metabolic activity especially when combined with standard chemotherapeutic regimes (FEC, TAC), whereas T-47D cells did not respond to gal-1 treatment. Therefore we hypothesize that gal-1 acts via TF on MCF-7 breast cancer cells.

\section{Conclusion}

Downregulation of tumour cell proliferation and onset of apoptosis by ligation of the TF epitope in breast cancer patients could be a first step of new therapeutic options. For applications in earlier development phases, homotypic tumor cell line spheroid models are the preferable choice to determining the impact of treatment on cancer cells separated out of a cell mixture in a complex tumor. But in vivo tumor tissue is a complex micro environmental structure, not only consisting of the organ specific tumor cells, but also of various types of stromal cells as well as the extra-cellular matrix and different soluble factors. Therefore predicting biological response to drug treatment in a 2D- or homotypic 3D model cannot perfectly reflect in vivo conditions. In a study in which spheroids were either generated homotypic from colon cancer tumor cell lines, or tumor cell lines co-cultured with stromal cells or spheroids directly prepared from colon cancer tissues, the three spheroid models reacted differently to the treatment with clinically relevant cancer combination therapies [25]. Therefore to evaluate the putative relevance galectin-1 and the ligation of the TF epitope could have in breast cancer treatment regimes, testing in heterotypic spheroid models could provide further information.
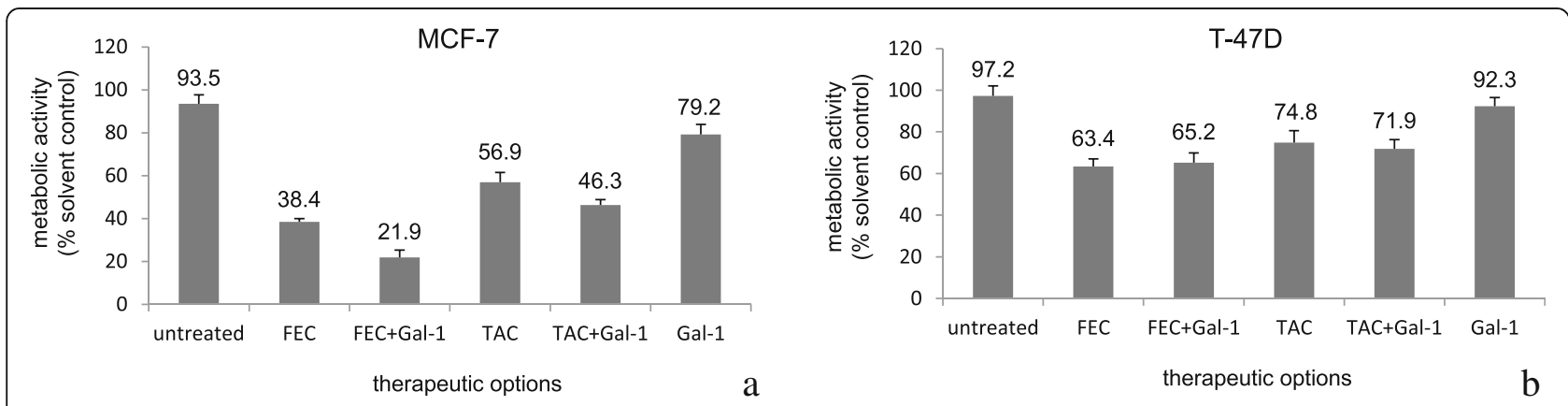

Fig. 5 Measurement of the metabolic activity of human breast cancer cells in spheroid culture in the ATP assay. Significant decrease of metabolic activity could be reached by incubation of MCF-7 cells with $30 \mu \mathrm{g} / \mathrm{ml}$ gal-1 compared to untreated cells ( $p=0.027$ ). In combination with $1 \times$ PPC FEC $(p=0.016)$ or 1 XPPC TAC $(p=0.031) 30 \mu \mathrm{g} / \mathrm{ml}$ gal-1 further significantly reduced the metabolic activity compared to FEC or TAC alone (a). In T-47D cells treatment with $30 \mathrm{\mu g} / \mathrm{ml}$ gal-1 could not significantly reduce the metabolic activity compared to untreated cells. Neither did the addition of $30 \mu \mathrm{g} / \mathrm{ml}$ gal-1 to 1xPPC FEC or 1xPPC TAC significantly alter the rate of metabolic activity compared to FEC or TAC alone (b) 


\section{Abbreviations}

ATP: Adenosine tri-phosphate; CRD: Carbohydrate recognition domain; FEC: Fluorouracil (F), epirubicin (E), cyclophosphamide (C); Gal-1: Galectin-1; TAC: Docetaxel (T), doxorubicin (A), cyclophosphamide (C); TF: ThomsenFriedenreich epitope

\section{Acknowledgements}

We thank C. Kuhn and S. Hofmann for technical support.

\section{Funding}

The study was supported by the German Research Council (DFG) for U Jeschke and the Federal Ministry of Education and Research within the national PROMEBS research project for B. Mayer.

\section{Availability of data and material}

Not applicable.

\section{Authors' contributions}

PG significantly contributed to data analysis, interpretation and statistical analysis, PG and UJ drafted the manuscript. IW and BM performed the experiments and both SS and BM significantly contributed to data analysis. $\mathrm{BM}, \mathrm{TW}$ and $\mathrm{UJ}$ revised the manuscript for important intellectual content. All authors approved the final version of the manuscript.

\section{Competing interests}

The authors declare that they have no competing interest.

\section{Ethics approval and consent to participate}

Because no patient material was used for this study, no ethical approval was necessary

\section{Author details}

'Department of Obstetrics and Gynecology, LMU Munich-Innenstadt, Maistrasse 11, 80337 München, Germany. 'Department of General, Visceral and Transplantation Surgery, Hospital of the LMU Munich, Marchioninistr 15, 81377 Munich, Germany.

Received: 11 July 2016 Accepted: 27 October 2016

Published online: 08 November 2016

\section{References}

1. Barondes SH, Cooper DN, Gitt MA, Leffler H. Galectins. Structure and function of a large family of animal lectins. J Biol Chem. 1994;269(33):20807-10.

2. La M, Cao TV, Cerchiaro G, Chilton K, Hirabayashi J, Kasai K, Oliani SM, Chernajovsky Y, Perretti M. A novel biological activity for galectin-1: inhibition of leukocyte-endothelial cell interactions in experimental inflammation. Am J Pathol. 2003;163(4):1505-15.

3. Perillo NL, Pace KE, Seilhamer JJ, Baum LG. Apoptosis of T cells mediated by galectin-1. Nature. 1995;378(6558):736-9.

4. Walzel H, Neels P, Bremer H, Kohler H, Raab N, Barten M, Brock J. Immunohistochemical and glycohistochemical localization of the beta-galactosidebinding S-type lectin in human placenta. Acta Histochem. 1995;97(1):33-42.

5. Hafer-Macko C, Pang M, Seilhamer JJ, Baum LG. Galectin-1 is expressed by thymic epithelial cells in myasthenia gravis. Glycoconj J. 1996;13(4):591-7.

6. Hughes RC. The galectin family of mammalian carbohydrate-binding molecules. Biochem Soc Trans. 1997;25(4):1194-8.

7. Raz A, Lotan R. Endogenous galactoside-binding lectins: a new class of functional tumor cell surface molecules related to metastasis. Cancer Metastasis Rev. 1987:6(3):433-52.

8. Adams L, Scott GK, Weinberg CS. Biphasic modulation of cell growth by recombinant human galectin-1. Biochim Biophys Acta. 1996;1312(2):137-44.

9. Wells $V$, Mallucci $L$. Identification of an autocrine negative growth factor: mouse beta-galactoside-binding protein is a cytostatic factor and cell growth regulator. Cell. 1991;64(1):91-7.

10. Offner H, Celnik B, Bringman TS, Casentini-Borocz D, Nedwin GE, Vandenbark AA. Recombinant human beta-galactoside binding lectin suppresses clinical and histological signs of experimental autoimmune encephalomyelitis. J Neuroimmunol. 1990;28(2):177-84.

11. Andre S, Kojima S, Yamazaki N, Fink C, Kaltner H, Kayser K, Gabius HJ. Galectins-1 and -3 and their ligands in tumor biology. Non-uniform properties in cell-surface presentation and modulation of adhesion to matrix glycoproteins for various tumor cell lines, in biodistribution of free and liposome-bound galectins and in their expression by breast and colorectal carcinomas with/without metastatic propensity. J Cancer Res Clin Oncol. 1999;125(8-9):461-74.

12. Bulmer JN, Johnson PM. Antigen expression by trophoblast populations in the human placenta and their possible immunobiological relevance. Placenta. 1985;6(2):127-40.

13. Proll J, Blaschitz A, Hutter H, Dohr G. First trimester human endovascular trophoblast cells express both HLA-C and HLA-G. Am J Reprod Immunol. 1999;42(1):30-6.

14. Grummer R, Hohn HP, Mareel MM, Denker HW. Adhesion and invasion of three human choriocarcinoma cell lines into human endometrium in a three-dimensional organ culture system. Placenta. 1994;15(4):411-29.

15. Jeschke U, Richter DU, Hammer A, Briese V, Friese K, Karsten U. Expression of the Thomsen-Friedenreich antigen and of its putative carrier protein mucin 1 in the human placenta and in trophoblast cells in vitro. Histochem Cell Biol. 2002;117(3):219-26.

16. Jeschke U, Karsten U, Wiest I, Schulze S, Kuhn C, Friese K, Walzel H. Binding of galectin-1 (gal-1) to the Thomsen-Friedenreich (TF) antigen on trophoblast cells and inhibition of proliferation of trophoblast tumor cells in vitro by gal-1 or an anti-TF antibody. Histochem Cell Biol. 2006;126(4):437-44.

17. Springer GF. T and Tn, general carcinoma autoantigens. Science. 1984; 224(4654):1198-206.

18. Springer GF. T and Tn pancarcinoma markers: autoantigenic adhesion molecules in pathogenesis, prebiopsy carcinoma-detection, and long-term breast carcinoma immunotherapy. Crit Rev Oncog. 1995;6(1):57-85.

19. Glinsky W, Huflejt ME, Glinsky GV, Deutscher SL, Quinn TP. Effects of Thomsen-Friedenreich antigen-specific peptide P-30 on beta-galactosidemediated homotypic aggregation and adhesion to the endothelium of MDA-MB-435 human breast carcinoma cells. Cancer Res. 2000:60(10):2584-8.

20. Wiest I, Seliger C, Walzel H, Friese K, Jeschke U. Induction of apoptosis in human breast cancer and trophoblast tumor cells by galectin-1. Anticancer Res. 2005;25(3A):1575-80.

21. Sutherland RM. Cell and environment interactions in tumor microregions: the multicell spheroid model. Science. 1988;240(4849):177-84.

22. Hamilton G. Multicellular spheroids as an in vitro tumor model. Cancer Lett. 1998;131(1):29-34.

23. Gaedtke L, Thoenes L, Culmsee C, Mayer B, Wagner E. Proteomic analysis reveals differences in protein expression in spheroid versus monolayer cultures of low-passage colon carcinoma cells. J Proteome Res. 2007;6(11):4111-8.

24. Remmele W, Stegner HE. [Recommendation for uniform definition of an immunoreactive score (IRS) for immunohistochemical estrogen receptor detection (ER-ICA) in breast cancer tissue]. Pathologe. 1987;8(3):138-40.

25. Hoffmann Ol, Imberger C, Magosch S, Joka M, Jauch KW, Mayer B. Impact of the spheroid model complexity on drug response. J Biotechnol. 2015:205:14-23.

26. Halfter K, Hoffmann O, Ditsch N, Ahne M, Arnold F, Paepke S, Grab D, Bauerfeind I, Mayer B. Testing chemotherapy efficacy in HER2 negative breast cancer using patient-derived spheroids. J Transl Med. 2016;14(1):112.

27. Springer GF, Desai PR. Depression of Thomsen-Friedenreich (anti-T) antibody in humans with breast carcinoma. Naturwissenschaften. 1975;62(6):302-3.

28. Springer GF, Murthy MS, Desai PR, Scanlon EF. Cellular immunity towards Thomsen-Friedenreich antigen in breast-carcinoma patients. Naturwissenschaften. 1976:63(6):300.

29. Yu LG. The oncofetal Thomsen-Friedenreich carbohydrate antigen in cancer progression. Glycoconj J. 2007;24(8):411-20.

30. Barr N, Taylor CR, Young T, Springer GF. Are pancarcinoma T and Tn differentiation antigens? Cancer. 1989:64(4):834-41.

31. van Rooijen JJ, Jeschke U, Kamerling JP, Vliegenthart JF. Expression of Nlinked sialyl Le(x) determinants and O-glycans in the carbohydrate moiety of human amniotic fluid transferrin during pregnancy. Glycobiology. 1998;8(11):1053-64

32. Baldus SE, Zirbes TK, Hanisch FG, Kunze D, Shafizadeh ST, Nolden S, Monig SP, Schneider PM, Karsten U, Thiele J, et al. Thomsen-Friedenreich antigen presents as a prognostic factor in colorectal carcinoma: A clinicopathologic study of 264 patients. Cancer. 2000;88(7):1536-43.

33. Takanami I. Expression of Thomsen-Friedenreich antigen as a marker of poor prognosis in pulmonary adenocarcinoma. Oncol Rep. 1999;6(2):341-4.

34. Carneiro F, Santos L, David L, Dabelsteen E, Clausen H, Sobrinho-Simoes M. $\mathrm{T}$ (Thomsen-Friedenreich) antigen and other simple mucin-type carbohydrate antigens in precursor lesions of gastric carcinoma. Histopathology. 1994;24(2):105-13. 
35. Hamada S, Furumoto H, Kamada M, Hirao T, Aono T. High expression rate of Tn antigen in metastatic lesions of uterine cervical cancers. Cancer Lett. 1993;74(3):167-73.

36. Hirao T, Sakamoto Y, Kamada M, Hamada S, Aono T. Tn antigen, a marker of potential for metastasis of uterine cervix cancer cells. Cancer. 1993;72(1):154-9.

37. Imai J, Ghazizadeh M, Naito Z, Asano G. Immunohistochemical expression of $\mathrm{T}, \mathrm{Tn}$ and sialyl-Tn antigens and clinical outcome in human breast carcinoma. Anticancer Res. 2001;21(2B):1327-34.

38. Wolf MF, Ludwig A, Fritz P, Schumacher K. Increased expression of Thomsen-Friedenreich antigens during tumor progression in breast cancer patients. Tumour Biology. 1988;9(4):190-4.

39. Schindlbeck C, Jeschke U, Schulze S, Karsten U, Janni W, Rack B, Sommer H, Friese K. Characterisation of disseminated tumor cells in the bone marrow of breast cancer patients by the Thomsen-Friedenreich tumor antigen. Histochem Cell Biol. 2005:123(6):631-7.

40. Schindlbeck C, Jeschke U, Schulze S, Karsten U, Janni W, Rack B, Krajewski S, Sommer H, Friese K. Prognostic impact of Thomsen-Friedenreich tumor antigen and disseminated tumor cells in the bone marrow of breast cancer patients. Breast Cancer Res Treat. 2007;101(1):17-25.

41. Cao Y, Schlag PM, Karsten U. Immunodetection of epithelial mucin (MUC1, MUC3) and mucin-associated glycotopes (TF, Tn, and sialosyl-Tn) in benign and malignant lesions of colonic epithelium: apolar localization corresponds to malignant transformation. Virchows Archiv. 1997;431(3):159-66.

\section{Submit your next manuscript to BioMed Central and we will help you at every step:}

- We accept pre-submission inquiries

- Our selector tool helps you to find the most relevant journal

- We provide round the clock customer support

- Convenient online submission

- Thorough peer review

- Inclusion in PubMed and all major indexing services

- Maximum visibility for your research

Submit your manuscript at www.biomedcentral.com/submit 